\title{
Fluoxetine decreased depressive symptoms in children and adolescents with non-psychotic major depressive disorder
}

\author{
Emslie GJ, Rush AJ, Weinberg WA, et al. A double-blind, randomized, placebo-controlled trial of fluoxetine in children and \\ adolescents with depression. Arch Gen Psychiatry 1997 Nov;54:1031-7.
}

\section{Objective}

To evaluate the efficacy and safety of fluoxetine in treating children and adolescents who have non-psychotic major depressive disorder (MDD).

\section{Design}

Randomised, double blind, placebo controlled trial with 8 weeks of follow up.

\section{Setting}

Outpatient mood disorders programme in Dallas, USA.

\section{Patients}

96 patients (mean age 12 y, $54 \%$ boys) who met the Diagnostic and Statistical Manual of Mental Disorders, 3rd edition, revised criteria for MDD. Exclusion criteria were bipolar disorder; psychotic depression; independent sleep wake disorder; substance abuse; anorexia nervosa; bulimia; previous treatment with fluoxetine, $20 \mathrm{mg} /$ day, for $\geqslant 3$ weeks; or a first degree relative with bipolar I disorder.

\section{Intervention}

48 patients received fluoxetine, $20 \mathrm{mg} /$ day, and 48 patients received a matching placebo.

\section{Main outcome measures}

Primary outcomes were response (Clinical Global Impressions [CGI] scale improvement rating) and depressive symptoms (Children's Depression Rating Scale-Revised [CDRS-R]) which were measured weekly by clinicians. Secondary outcomes were global functioning (Children's Global Assessment Scale) and general psychopathology (Brief Psychiatric Rating Scale-Children) which were also assessed weekly by clinicians. Patient self reports of depressive symptoms at the beginning and the end of treatment were also used (Beck Depression Inventory or the Children's Depression Inventory and the Weinberg Screening Affective Scale).

\begin{abstract}
Main results
Analysis was by intention to treat. Patients who received fluoxetine were more likely to be much or very much improved according to the CGI scale improvement rating than patients who received placebo $(\mathrm{p}=0.02)$ (table). Compared with placebo, fluoxetine led to lower CDRS-R scores at week $5(\mathrm{p}<0.03)$, week $6(\mathrm{p}<0.04)$, week $7(\mathrm{p}<0.04)$, and week $8(\mathrm{p}<0.008)$. Treatment was stopped due to lack of efficacy in 7 and 19 patients receiving fluoxetine and placebo, respectively $\{\mathrm{p}=0.006\}^{*}$, and due to side effects in 4 and 1 patients receiving fluoxetine and placebo, respectively $\{\mathrm{p}=0.36\}^{*}$. Improvement in general psychiatric symptoms, global functioning, and self reported depressive symptoms did not differ between treatments.
\end{abstract}

\section{Conclusion}

Compared with placebo, fluoxetine was effective and safe in the treatment of children and adolescents who had non-psychotic major depressive disorder.

* p values calculated from data in article.

Fluoxetine v placebo in children with non-psychotic major depressive disordert

\begin{tabular}{llllll}
\hline $\begin{array}{l}\text { Outcome at } \\
8 \text { weeks }\end{array}$ & $\begin{array}{l}\text { Fluoxetine } \\
\text { EER }\end{array}$ & $\begin{array}{l}\text { Placebo } \\
\text { CER }\end{array}$ & $\begin{array}{l}\text { RBI } \\
(95 \% \text { CI })\end{array}$ & $\begin{array}{l}\text { ABI } \\
\mid \text { EER - CER } \mid\end{array}$ & $\begin{array}{l}\text { NNT } \\
\text { (CI) }\end{array}$ \\
\hline $\begin{array}{l}\text { Much or very } \\
\text { much }\end{array}$ & & & & $59 \%$ \\
improved & $56 \%$ & $33 \%$ & $\begin{array}{l}(7 \text { to } 174) \\
\text { (3 to 33) }\end{array}$ & $23 \%$ & (3)
\end{tabular}

†Abbreviations defined in glossary; RBI, ABI, NNT, and CI calculated from data in article.

Source of funding: National Institute of Mental Health.

For article reprint:Dr GJ Emslie, Department of Psychiatry, University of Texas Southwestern Medical Center at Dallas, 5323 Harry Hines Boulevard,Dallas, TX 75235-9070, USA. Fax +1 214640 5941.

Abstract and commentary also published in Evidence-Based Medicine $1998 \mathrm{Jul}$-Aug.

\section{Commentary}

This study by Emslie et al is a landmark study for child and adolescent psychiatry. It is the largest randomised controlled trial (RCT) to date of an antidepressant medication in a child and adolescent population, the first such study to report a superior drug response compared with placebo for adolescents, the second to do so for children, ${ }^{1}$ and the first to use an intent to treat analysis.

The finding of fluoxetine and placebo response rates comparable to those from RCTs of fluoxetine and other antidepressants in adults, ${ }^{2}$ and the finding of no age group by treatment interaction suggest that depressed individuals of all ages may be similar in their response to antidepressant medication. Until now, RCTs of depressed children and adolescents have been plagued by small samples. ${ }^{3}$ Although this is the largest study to date, it is worth noting that it took almost 4 years to complete. Multicentre trials are essential if important research findings from populations of depressed children and adolescents are to be relayed to clinicians in a timely fashion. In the meantime, the use of antidepressants in depressed children and adolescents is widespread despite lack of evidence for their efficacy from RCTs. ${ }^{4}$ Clinicians now have this exemplary study to support their current use of fluoxetine, but it is unlikely that its publication will lead to major changes in clinical practice.

Finally, it is important to note that less than one third of patients treated with fluoxetine achieved complete remission of their symptoms. This suggests that either a longer duration of treatment with fluoxetine or the use of adjunctive treatments in this population is required, or both.

Jan Fleming, MD, FRCPC Chedoke-McMaster Hospitals Hamilton, Ontario, Canada

1 Preskorn SG, Weller EB, Hughes CW, et al. Psychopharmacol Bull 1987;23:128-33.

2 Frank E, Karp JF, Rush AJ. Efficacy of treatments for major depression. Psychopharmacol Bull 1993;29:457-75.

3 Hazell P, O'Connell D, Heathcote D, et al. BMJ 1995;310:897-901.

4 Johnston HF, Fruehling JJ. In: Reynolds WM, Johnston HF, editors. Handbook of depression in children and adolescents. New York: Plenum children and adolescent

5 Klemm AL, Carlson JS, Johnston H, et al. J Am Klemm AL, Carlson JS, Johnston H, et al. J Am
Acad Child Adolesc Psychiatry 1997;36:1016-7. 